\title{
The Effect of Salinity on Growth, Dry Weight and Lipid Content of the Mixed Microalgae Culture Isolated from Glagah as Biodiesel Substrate
}

\author{
Eko Agus Suyono ${ }^{1}$, Winarto Haryadi ${ }^{2}$, Muhammad Zusron ${ }^{1}$, Matin Nuhamunada ${ }^{1}$, Sri Rahayu ${ }^{1}$ and Andhika \\ Puspito Nugroho ${ }^{1}$ \\ 1. Faculty of Biology, Universitas Gadjah Mada, Yogyakarta 55281, Indonesia \\ 2. Department of Chemistry, Faculty of Mathematics and Natural Sciences, Universitas Gadjah Mada, Yogyakarta 55281, Indonesia
}

Received: May 9, 2015 / Accepted: May 30, 2015 / Published: May 30, 2015.

\begin{abstract}
Microalgae use photosynthesis to convert solar energy into chemical energy, such as lipid and they can be a replacement for oil-based fuels. They are among the fastest growing plants in the world, and about $50 \%$ of their weight is oil. This lipid oil can be used to make biodiesel. Unfortunately, there are only some of potential strains isolated from Indonesia and most of the biodiesel productions are usually using a single strain. Then, although they are rich of oils, their biomass productivity is still low. Salinity treatment can be used to increase their biomass as well as their lipid content. Therefore, the research aim was to study the effect of salinity on the growth, dry weight and lipid content of mixed microalgae isolated from Glagah, Yogyakarta. The mixed microalgae were cultured in 3NBBM medium with different salinities or types of water (sea water, brackish water, and fresh water). The cultures were incubated at light intensity 3,000 lux under dark:light exposure of 12:12 h for 7 days. The number of cells was counted every $24 \mathrm{~h}$ with a Haemocytometer, and the biomass was calculated based on the dry weight. The lipid content was measured on days 0,3 , and 7 using NR (Nile Red) staining, and then the amount of lipid was analyzed using a fluorescence microscope and measured with CellProfiler 2.0 software. The highest dry weight and lipid content were found in seawater medium, they accounted for $3.42 \mathrm{mg} / \mathrm{mL}$ and $13.58 \%$ at day 7 , respectively. Whereas, the highest number of cells was found in freshwater medium, this was $9.8 \times 10^{6}$ cells $/ \mathrm{mL}$.
\end{abstract}

Key words: Salinity, growth, dry weight, lipid content.

\section{Introduction}

The worldwide increase of human population and transportation has generated greater energy consumption of petroleum fossil fuels that lead energy crisis because of depleting fossil fuel reserves [1]. Therefore, for solving the issue above, a renewable energy as an alternative resource should be developed. Microalgae-based biodiesel production could be a potential source for the future renewable energy [2]. Microalgae as a potential candidate for biodiesel production has generated significant interest [3, 4], because the organism is the most efficient biological

\footnotetext{
Corresponding author: Eko Agus Suyono, research field: algal biotechnology and engineering. E-mail: eko_suyono@ugm.ac.id.
}

producer of oil and biomass source due to use photosynthesis to convert solar energy and combine water with fixing $\mathrm{CO}_{2}$ into chemical energy, such as lipid and it can be a replacement for oil-based fuel [5, 6].

Currently, biodiesel production were dominated by commercial single strains microalgae [3]. Most of the commercial single cell cultivations of microalgae have low biomass production and lipid content due to various problems such as culture condition and susceptibility to contaminant [7]. Those problems can be overcome through the search and selection of the local microalgae strains for biodiesel production which have highest growth rate, biomass productivity, and lipid content $[8,9]$. Furthermore, the use of mixed 
culture of the selected local strains shows that cells grow faster and high biomass yield because the cells are capable for utilizing organic carbon sources optimally [10].

Even so, optimization technology is commonly done by regulating environmental conditions and culture medium [11]. By adjusting the salinity was reported able to increase biomass production, such as in Scenedesmus almeriensis culture [12] and Scenedesmus sp. culture [13]. Moradi and Ismail [14] also reported that Botryococcus braunii adapted to grow in low salinity was able to increase the biomass production, hydrocarbon, fat, carbohydrate, and carotenoids. Microalgae have a response against increase of salinity and osmotic stress on the environment by accumulating small molecules components for osmoregulation [6]. Hu [15] and Rao et al. [16] describe that the increasing of salinity leads to slight increase in the total lipid content of algae, but excessive salinity gives an negative effect on growth due to salt stress causes microalgae tend colonies-form in the growth phase, inhibit the photosynthesis and decrease the growth rate.

Therefore, it is important to study the effect of different salinities in culture medium of the mixed microalgae culture isolated from Glagah cell on growth, dry weight, and lipid content for biodiesel substrate.

\section{Materials and Methods}

\subsection{Algal Cultures}

The mixed microalgae culture isolate Glagah were obtained from Glagah beach in the coastal area of South Yogyakarta-Indonesia. Microalgae samples were isolated in Laboratory of Biotechnology, Faculty of Biology, UGM by using the microcapillary pipette method and serial dilution method [17]. The isolated microalgae was not identified yet, however, according to morphological characters, they consisted of three genus, there were Chlorella, Scenedesmus [18], and Nannochloropsis [19].
The strains were cultivated in modified sea water medium of $f / 2$ for selection. Then, survived strains were cultivated in modified 3NBBM medium + vitamins medium [20] They were grown in $500 \mathrm{~mL}$ glass bottles and incubated at light intensity of 3,000 lux under dark:light exposure of $12: 12 \mathrm{~h}$ for 7 days at $18-25^{\circ} \mathrm{C}$.

\subsection{Cultivation Condition with Different Salinity}

For all experiments, the microalgae were grown in modified 3NBBM medium + vitamin in $500 \mathrm{~mL}$ glass bottle under condition described above. The effect of salinity was investigated at $3 \mathrm{NBBM}+$ vitamins diluted in fresh water, sea water, and brackish water (mixture of fresh water:sea water $(1: 1)$ ) with three replications. The cultures were inoculated into glass bottles of different salinity medium with ratio $50 \mathrm{~mL}$ stock culture and $200 \mathrm{~mL}$ the medium.

\subsection{Determination of Cells Growth}

To compare cell growth in different salinity, cells were counted using a light microscope and Haemocytometer Neubauer $1 \mathrm{~mm}$ every $24 \mathrm{~h}$. Sample was shaken to homogenize, then $900 \mu \mathrm{L}$ of sample put into microtube $2 \mathrm{~mL}$ mixed with $100 \mu \mathrm{L}$ of alcohol $70 \%$ for fixing. Number of cells was calculated as follows:

Cell number $=$ cell count $\times 5 \times 10^{4} \mathrm{cell} / \mathrm{mL}$

\subsection{Determination of Algal Biomass}

The biomass production was measured based on dry weight of the culture for seven days. Sample culture (2 $\mathrm{mL}$ ) was transferred into microtube $2 \mathrm{~mL}$. Sample was centrifuged at 3,300 rpm for $10 \mathrm{~min}$. Supernatant was discarded, then washed using distillate water. Cell suspensions on micro tube bottom were dried in the incubator oven at $34{ }^{\circ} \mathrm{C}$ until having constant weight.

\subsection{Determination of Lipid Content by Nile Red Staining}

Lipid content was measured by using Nile Red 
(9-(Diethylamino)-5H-benzophenoxazin-5-one) staining [21]. Nile red staining was conducted to detect intracellular lipid droplets [22]. The cultured cells $(1 \mathrm{~mL})$ were collected into micro tube and 0.01 $\mathrm{mg} / \mathrm{mL}$ then was added with Nile Red for staining. Stained microalgae cells were observed by Fluorescent Microscope to get the lipid fluorescence. The lipid fluorescence from neutral lipid will be smeared yellow-orange [21, 23]. Then, lipid fluorescences were quantified using image analysis software CellProfiler 2.0 as an intracellular lipid droplet [24].

\section{Results and Discussion}

The comparison of, cell growth, dry weight, cell quota and lipid content in mixed cultures of microalgae isolated from Glagah, Yogyakarta using various salinities of medium in bacth cultures were investigated. Those data are presented in Figs. 1a-1d.

As can be seen from Fig. 1a., the microalgae were growth better in fresh water medium as similar to their habitat. The highest number of cells was found in freshwater medium reached $9.8 \times 10^{6}$ cells $/ \mathrm{mL}$ at day 7, followed by brackish water and sea water treatments. However, the highest total dry weight was found in sea water treatment accounted for 3.42 $\mathrm{mg} / \mathrm{mL}$, followed by brackish water and fresh water. Both sea water and brackish water treatments reached a pick at day 5, but fresh water treatment was at a pick at day 4. (Fig. 1b). It can be assumed that microalgae growth in fresh water medium were stimulated to proliferate their cells rather than construct their cell walls. The fresh water nutrient absorbed by microalgae cells did not used much to construct the cell wall, but to stimulate cell division. Then, their cells became smaller and their cell walls were relatively thinner and lighter. On the other hand, sea water nutrient provided more and suitable compounds for producing carbohydrate stored in the cell walls as sellulose and hemiselluse, so that the total dry weight was higher.
The trend of cell quota (dry weight per cells) of each treatment (Fig. 1c) was different from total dry weight (Fig. 1b). The highest cell quota was in the brackish water treatment at day 5 with reached 3.79 $\mathrm{ng} / \mathrm{cell}$, followed by sea water treatment and fresh water treatment, they accounted for $1.52 \mathrm{ng} / \mathrm{cell}$ and $0.17 \mathrm{ng} / \mathrm{cell}$, respectively (Fig. 1c). Therefore, the total dry weight in sea water was the highest, but the dry weight per cells in brackish water was the highest. This happened because the cell division in brackish water was growth very slow (Fig. 1a).

Lipid contents of the microalgae in all treatments tend to increase during their growth. The highest lipid content of the microalgae was found in seawater treatment at day 7 accounted for $13.58 \%$, followed by brackish water treatment (5.86\%), and the lowest was found in fresh water treatment $(0.88 \%)$ (Fig. 1d). Increasing of lipid content was caused by the accumulation of lipid under stress conditions. These results were similar to the research done by Takagi et al. [25] in Dunaliella cells. This was also confirmed by $\mathrm{Hu}$ [15] that the increase of salinity could accelerate the total lipid content in microalgae cells. Under high salinity condition, the microalgae were stimulated to enhance their lipid production as osmoprotectant which necessary to protect them from salt stress [26]. High salinity water might effect on intracellular osmolarity due to hypertonic medium condition over the microalgae cells. Then, it caused release of water inside of the microalgae cells into the environment. The mechanisms for encountering salinity stress were regulated by producing lipid in large quantities to prevent the escape of water from microalgae cells. So, the high amounts of lipid lead to enhancing the microalgae dry weight. Therefore, the high salinity treatment could be used as method to increase the biomass productivity and stimulate lipid production of microalgae for biodiesel substrates.

\section{Conclusions}

Different salinity have potential for increase the 


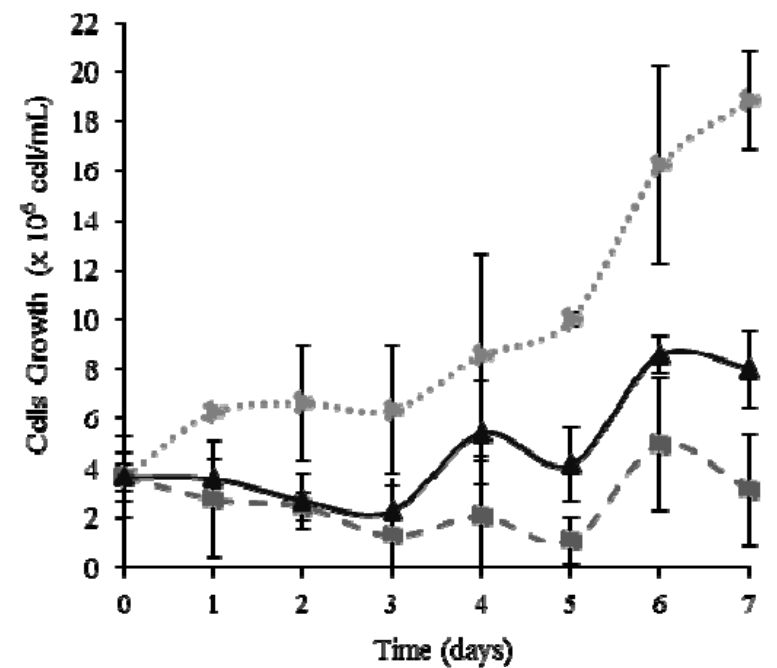

(a)

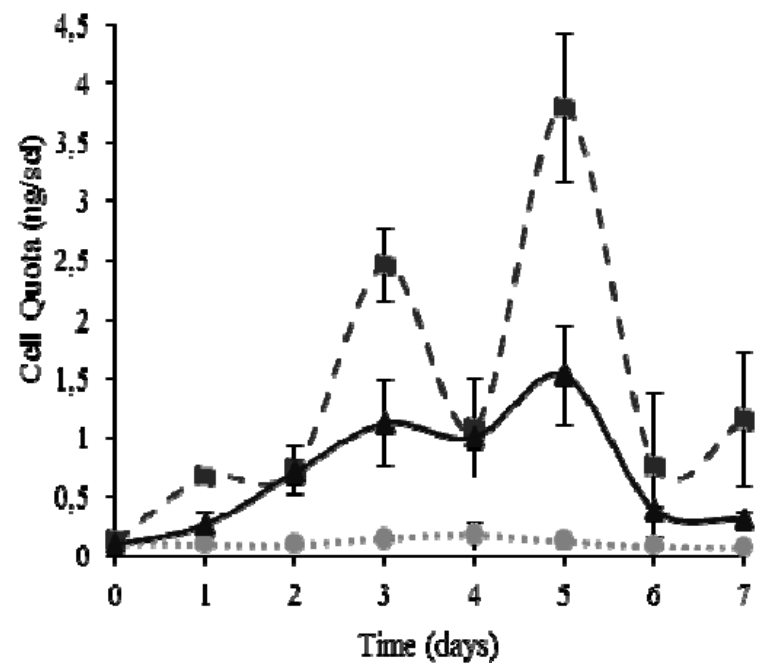

(c)

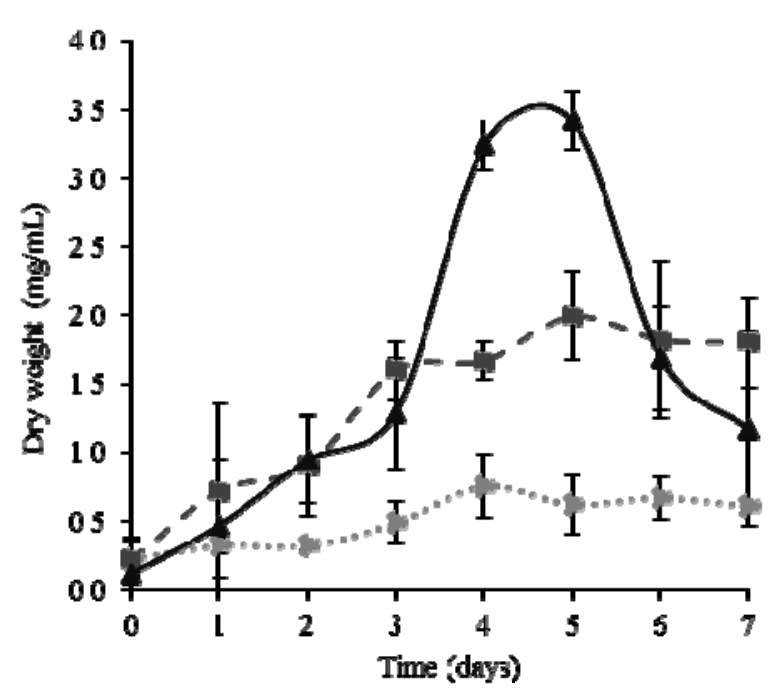

(b)

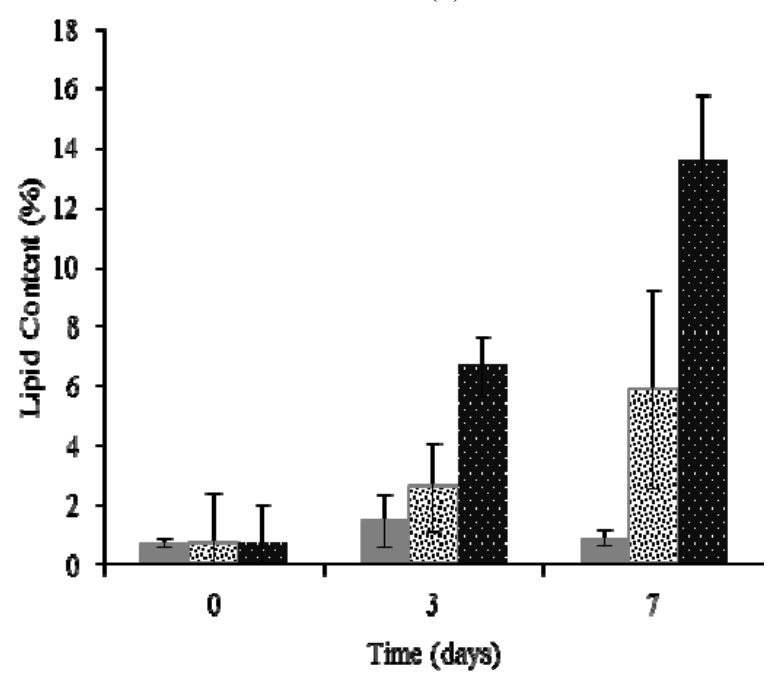

(d)

Fig. 1 Growth (A), dry eight (B), cell quota (C) and lipid content (D) of the mixed microalgae cultures isolated from Glagah were cultured in fresh water $(\Theta)$, brackish water $(\square)$, and sea water $(\Delta)$.

number of cells, dry weight and lipid content on the mixed microalgae cultures isolates from Glagah. The highest dry weight and lipid content were found in seawater medium, they accounted for $3.42 \mathrm{mg} / \mathrm{mL}$ and $13.58 \%$ at day 7 , respectively. Whereas, the highest number of cells was found in freshwater medium, this was $9.8 \times 10^{6}$ cells $/ \mathrm{mL}$.

\section{Acknowledgments}

All authors would like to sincerely acknowledge to Directorate General of Higher Education, Ministry of
Education and Culture, Indonesia for funding this research.

\section{References}

[1] Amin, S. 2009. "Review on Biofuel Oil and Gas Production Processes from Microalgae." Energy Conversion and Management 50: 1834-40.

[2] Chisti, Y. 2008. "Biodiesel from Microalgae Beats Bioethanol." Trends in Biotechnology 26: 126-31.

[3] Chisti, Y. 2007. "Biodiesel from Microalgae." Biotechnology Advances 25: 296.

[4] Gouveia, L. and Oliveira, A. C. 2009. "Microalgae as Raw Material for Biofuels Production." Journal of 
Industrial Microbiology Biotechnology 36: 269-74.

[5] Demirbas, A. 2010. "Use of Algae as Biofuel Sources." Energy Conversion and Management 51: 2738-49.

[6] Richmond, A. 2004. Handbook of Microalgal Culture: Biotechnology and Applied Phycology. India: Blackwell Science.

[7] Ogbonna, J. C., Yoshizawa, H., and Tanaka, H. 2000. "Treatment of High Strength Organic Wastewater by a Mixed Culture of Photosynthetic Microorganism." Journal of Applied Phycology 12: 277-84.

[8] Mutanda, T., Ramesh, D., Karthikeyan, S., Kumari, S., Anandraj, A., and Bux, F. 2011. "Bioprospecting for Hyper-Lipid Producing Microalgae Strains for Sustainable Biofuel Production." Bioresource Technology 102: 57-70.

[9] Griffiths, M. J. and Harrison, S. T. L. 2009. "Lipid Productivity as Key Characteristic for Choosing Algal Species for Biodiesel Production." Journal of Applied Phycology. 276: 23-5.

[10] Friday, E. T. 2010. "Mixed Cultivation of Euglena gracilis and Chlorella sorokiniana: A Production Method of Algae Biomass on a Large Scale." Journal of Applied Biosciences 35: 2225-34.

[11] Hu, Q., Sommerfeld, M., Jarvis, E., Ghirardi, M., Posewitz, M., Seibert, M., and Darzins, A. 2008. "Microalgal Triacylglycerols as Feedstocks for Biofuel Production: Perspectives and Advances." The Plant Journal 54: 621-39.

[12] Kaewkannetra, P., Enmak, P., and Chiu, T. Y. 2012. "The Effect of $\mathrm{CO}_{2}$ and Salinity on the Cultivation of Scenedesmus obliquus for Biodiesel Production." Biotechnology and Bioprocess Engineering 17: 591-97.

[13] Peng, J., Yin, K., Yuan, J. P., Cao, G. X., Xue, M., Wu, S. F., and Wang, J. H. 2012. "Characterization of a Newly Isolated Green Microalgae Scenedesmus sp. as a Potential Source of Biodiesel." African Journal of Biotechnology 11 (9): 16083-94.

[14] Moradi, M., and Ismail, A. M. 2007. "Responses of Photosynthesis, Chlorophyll Fluorescence and ROS-Scavenging Systems to Salt Stress. During seedling and Reproductive Stages of Rice." Annals of Botany 99: 1161-73.

[15] Hu, Q. 2004. "Environmental Effects on Cell Composition." In Handbook of Microalgae Culture: Biotechnology and Applied Phycology, edited by Richmond, A. Victoria: Blackwell.
[16] Rao, A. R., Dayananda, C., Sarada, R., Shamala, T. R., and Ravishankar, G. A. 2007. "Effect of Salinity on Growth of Green Alga Botryococcus braunii and Its Constituents." Bioresource Technology 98: 560-4.

[17] Andersen, R. A. 2005. Algal Culturing Techniques. London: Elsevier Academic Press.

[18] Vuuren, S. J. V., Taylor, J., Ginkel, C. V., and Gerber, A. 2006. Easy Identification of the Most Common Freshwater Algae: A Guide for the Identification of Microscopic Algae in South African Freshwaters. Pretoria: Resource Quality Services.

[19] Elumalai, S., Sakthivel, R., Santhose, B. I., and Murugan, P. A. 2011. "Isolation, Identification, Morphological Studies and Lipid Granules Staining (Nile Red) of Different Microalgae for Biodiesel Production from Fresh Water and Saline Water." Journal of Experimental Sciences 2 (7): 26-9.

[20] Aghajanian, J. G. 1979. “A Starch Grain-Mitochondrion Dictyosome Association in Batrachospermum (Rhodophyta)." Journal of Phycology 15: 230-2.

[21] Qin, J. 2005. Bio-Hidrocarbon from Algae: Impact of Temperature, Light and Salinity on Algae Growth. Rural Industries Research and Development Corporation. Australian Government. pp.13.

[22] Greenspan, P., Mayer, E. P., and Fowler, S. D. 1985. "Nile Red: A Selective Fluorescent Stain for Intracellular Lipid Droplets." Journal of Cell Biology 100: 965-73.

[23] Carman, K. R., Thistle, D., Ertman, S. C., and Foy, M. 1991. "Nile Red as a Probe for Lipid-Storage Products in Benthic Copepods." Marine Ecology Progress Series 74: 307-11.

[24] Carpenter, A. E., Jones, T. R., Lamprecht, M. R., Clarke, C., Kang, I. H., and Firman, O. et al. 2006. "CellProfiler: Image Analysis Software for Identifying and Quantifying Cell Phenotypes." Genome Biology 7 (10): 100.

[25] Takagi, M., Karseno., Yoshida, T. 2006. "Effect of Salt Concentration on Intracellular Accumulation of Lipids and Triacylgliceride in Marine Microalgae Dunaliella Cells." Journal of Bioscience and Bioengineering 101: 223-6.

[26] Singh, S. P., and Montgomery, B. L. 2013. "Salinity Impacts Photosynthetic Pigmentation and Cellular Morphology Changes by Distinct Mechanisms in Fremyella Diplosiphon." Biochemical and Biophysical Research Communications 433: 84-9. 